\title{
Ukraina: oranžinè revoliucija ir kas po to?
}

\begin{abstract}
Šio straipsnio tikslas - aptarti Oranžinės revoliucijos Ukrainoje priežastis ir išsiaiškinti, kaip politinio režimo pokyčiai veikè Kijevo užsienio politikos kursą. Pirmoje straipsnio dalyje aiškinamasi, kokie vidiniai ir išoriniai veiksniai sąlygojo politinio režimo transformaciją 2004 metu pabaigoje - 2005 metu pradžioje. Atsakoma i klausima, kodèl Ukrainoje įvyko Oranžinè revoliucija. Remiamasi prielaida, jog politinio režimo transformaciją veikẻ ne tik vidinès aplinkybės (pirma, oligarchinio politinio režimo krizè), bet ir išorinès. Vakarai ir Rusija vertina Ukrainą kaip strategiškai svarbią valstybę, todèl ji tampa ypatinga varžybų dèl ịtakos tarp Vakarų struktūrų ir Rytų objektu. Pažymètina, jog toks interesu persidengimas yra dinaminis procesas: jis gali sąlygoti stabilumo ir bendradarbiavimo tarp Vakaru ir Rytų tendencijas arba konfliktiškumą. Straipsnyje daroma išvada, jog artimiausiu laiku Ukraina gali tapti įtampos ir konfliktu tarp Rusijos ir Vakaru (pirmiausia JAV) židiniu. Antroje straipsnio dalyje atsakoma į klausimą, kaip 2005 metais rugsèjo politinè krizé, Viktoro Juščenkos ir Julijos Timošenkos aljanso skilimas, Rusijos bei Ukrainos dujų konfliktas gali veikti šalies užsienio politikos tendencijas iki 2006 metu kovo Rados rinkimų. Straipsnyje pažymima, jog, nepaisant sudėtingos socialinès ir ekonominès situacijos, politiniu krizių Kijevas stengėsi išlaikyti provakarietišką užsienio politikos kursą. Ypač suaktyvèjo Ukrainos bendradarbiavimas su NATO bei regioninè Kijevo politika. Tokias tendencijas Ukrainos užsienio politikoje aktyviai remia JAV, taip tikèdamasi vakarinejje NVS dalyje sukurti atsvarą Rusijos siekiams atkurti čia savo įtaką. Antra vertus, toks Kijevo aktyvumas aštrina santykius su Maskva. Straipsnyje teigiama, jog tolesnis Ukrainos ir Vakarų struktūrų bendradarbiavimas priklausys nuo 2006 metu kovo ménesio Rados rinkimu.
\end{abstract}

\section{Ivadas}

Paprastai studijose, kuriose aptariama Ukrainos raida po Šaltojo karo, daugiausia demesio skiriama valstybingumo konsolidacijos, ekonominių - politinių reformų igyvendinimo klausimams. Taip pat plačiai aptarinejjamos Ukrainos saugumo bei užsienio politikos kaitos tendencijos, vadinamosios daugiavektoriškumo politikos sklaida, santykiai su Vakarų struktūromis bei Rusija. Dažniausiai autoriai, analizuodami Ukrainos užsienio politikos dinamiką, pažymi, jog ji buvo sąlygota ypatingos geopolitinès šalies padèties. Kitaip tariant, teigiama, jog Ukrainos užsienio ir saugumo politika sąlygojama ne tik vidinių

Dr. Vladas Sirutavičius - Vilniaus universiteto Tarptautiniu santykių ir politikos mokslu instituto docentas, Viešosios įstaigos „Ukrainos institutas" direktorius. Adresas: Vokiečiu 10, 01130 Vilnius, tel. 85 2514138, el. paštas: siruvlad@takas.lt. 
veiksnių specifikos (regionalizmo, specifinès „oligarchinės politinės“ sistemos), bet ir tos aplinkybès, kad šalis yra dvieju „ "persidengiančių integracinių erdvių" sandūroje. Pažymima, jog Ukraina yra veikiama i Vidurio Rytų Europą išsiplètojusiu Vakarų struktūru „,kaimynystès“, pasireiškiančios vadinamosiomis Europos Sajungos ir NATO Rytu politikomis ir kartu tiesiogiai veikiama Rusijos ${ }^{1}$.

Pastebėtina, jog šiuo metu vis dažniau diskutuojama apie politinio režimo transformaciją 2004 metu pabaigoje - 2005 metu pradžioje. Anot optimistų, Oranžinè revoliucija sudare palankias prielaidas politinès bei ekonominėms reformoms šalyje bei spartesnei Ukrainos integracijai i Vakarų struktūras. Atsargesnio požiūrio autoriai mano, kad Oranžinè revoliucija susiduria su vis sunkesniais išbandymais šalies viduje, o tai neigiamai veikia ir integracijos i Vakarų struktūras politinį kursą. (Beje, tokias nuostatas patvirtina 2005 metais rugsëjo mèn. kilusi valdžios krizè ir provakarietišku, demokratiniu jëgų skilimas.) Vis dažniau pasigirsta vertinimu, jog Oranžinè revoliucija nepasiekè savo svarbiausių tikslų ${ }^{2}$.

Šis straipsnis turi du svarbiausius tikslus. Pirma, išsiaiškinti, kokie vidiniai ir išoriniai veiksniai sąlygojo politinio režimo transformaciją 2004 metu pabaigoje - 2005 metų pradžioje. Taigi siekiama atsakyti į klausimą, kodėl Ukrainoje tapo įmanoma Oranžinè revoliucija. Remiamasi prielaida, jog politinio režimo transformaciją veikė ne tik vidinės aplinkybės (pavyzdžiui, politinės sistemos ypatybės), bet ir struktūrinio persidengimo pobūdis. Kitaip tariant, Vakarai ir Rusija vertina Ukrainą kaip strategiškai svarbią valstybę, todẻl ji tampa ypatingu varžybų dèl įtakos tarp Vakarų struktūrų ir Rytų objektu. Pažymėtina, jog struktūrinis persidengimas yra dinaminis procesas: jis gali sąlygoti stabilumo ir bendradarbiavimo tarp Vakarų ir Rytų tendencijas arba konfliktiškumą.

Antra, straipsnyje siekiama atsakyti į klausimą, kaip rugsëjo politinė krizė ir, kas dar svarbiau, kaip Viktoro Juščenkos ir Julijos Timošenkos aljanso skilimas gali veikti šalies užsienio politikos tendencijas per artimiausią laiką, $\mathrm{t}$. y. iki 2006 metų kovo Rados rinkimų.

${ }^{1}$ Žr.: Bugajski J., Cold Peace. Russia's New Imperialism, West-Port: Praeger Publisher, 2004, p. 79-95 Brzezinski Z., The Grand Chessboard. American Primacy and Its Geostrategic Imperatives, Basic Books, 1997, p. 126-138. Taip pat lietuvių autorių Laurinavičius Č., Motieka E., Statkus N., Baltijos valstybiu geopolitikos bruožai XX amžius, Vilnius, LII leidykla, 2005, p. 357-374.

${ }^{2}$ Palyginti Kuzio T., „From Kuchma to Yushchenko. Ukraine's 2004 Presidential Elections and the Orange Revolution“, Problems of Post-Communism, vol. 52, no. 2, March/April 2005, p. 29-42 ir D'Anieri P., "What Has Changed in Ukrainian politics? Assessing the implications of Orange Revolution“", Problems of Post-Communism, vol. 52, no. 5, September/October 2005, p. 82-91. 


\section{1. „Oranžinè" režimo transformacija: vidinès ir išorinès priežastys}

Problema, kurią aptarsime šioje dalyje, trumpai galima būtų suformuluoti taip: kodèl Ukrainoje sužlugo politinės valdžios „perdavimo“ procesas? Kitaip tariant, kodèl dominuojančiam politiniam elitui, jo lyderiui, net ir naudojantis vadinamojo administracinio resurso teikiamomis galimybèmis bei manipuliuojant ",demokratiniais rinkimais", vis dèlto nepavyko išsaugoti (perduodant valdžią savo statytiniui) įtakos politinëje sistemoje. Beje, kitose NVS erdvės šalyse ši politinè „operacija“ paprastai būdavo realizuojama pakankamai sèkmingai. Akivaizdu, jog Ukrainoje vykę prezidento rinkimai turëjo tik pridengti, užmaskuoti „,valdžios perdavimą“. Tokị „,valdžios perdavimo“ žlugimo proce$s q$ analitikai ir pavadino revoliucija ${ }^{3}$.

Paprastai teorijose, kuriose aiškinamos revoliucijų priežastys bei pobūdis, pažymima, jog jų raidą (sẻkmę ar nesẻkmę) lemia vidinių (struktūriniai) bei išoriniu (tarptautinès aplinkos poveikis) veiksnių kombinacija. Panašiai bandoma aiškinti ir įvykius Ukrainoje. Štai Dmitrijaus Trenino teigimu, „buržuazinès demokratinès revoliucijos" Ukrainoje negalëjo sukelti vien tik išorinio veiksnio poveikis: Vakarų įtaka ar Kremliaus klaidos. Egzistavo ir svarbios vidinès priežastys: L. Kučmos siekis visokiais būdais išsaugoti valdžią, režimo krizė, politinio elito skilimas, opozicijos teisingai pasirinkta taktika, viduriniosios klasės mobilizacija Kijeve, masinių informacijos priemoniu poveikis, galiausiai režimo nesugebëjimas griebtis prievartos ir neutralizuoti opozicijos lyderius ${ }^{4}$.

Panašiai, tik jau kaip „oranžinė revoliucija“, aiškinama ir Vakarų analitiku studijose. Jose pabrèžiama, kad revoliucija Ukrainoje buvusi „demokratinių revoliucijų "Vidurio Europoje, vèliau Serbijoje bei Gruzijoje tąsa. Iš esmės jas galima vertinti kaip „,visuomenių sukilimą“, tiesa, taiku prieš korumpuotus, nedemokratinius režimus ${ }^{5}$. Žemiau aptarsime kelis struktūrinius veiksnius, mūsų nuomone, turëjusius reikšmingos įtakos revoliucinei politinès krizès Ukrainoje atomazgai.

\subsection{Vidinès režimo transformacijos prielaidos}

\subsubsection{Politinio režimo pliuralizmas}

Neneigiant tos aplinkybės, jog Leonido Kučmos režimas buvo nedemokratinis, vis dèlto reikètu pažymèti, kad jis išliko pakankamai pliuralistinis bei atviras. Kitaip tariant, opozicija, nors ir administraciniu būdu ribojama, turëjo santykiškai neblogas politinio veikimo sąlygas. Ši aplinkybẻ leido apie populia-

\footnotetext{
${ }^{3}$ Pipes R., "In „Bordeland“. The Struggle for Ukraine“, National Review, December 27, 2004, p. 20.

${ }^{4}$ Тренин Д., „Внешнее вмешательство в события на Украине и Российско - Западные отношения“,

Московский центр Карнеги. Брифинг, вып.2., т. 7, 2005, с. 1-6.
} 
rų 2001 metais Kučmos atleistą ekspremjerą Viktorą Juščenką susitelkti įvairioms, dažnai ideologiniu pagrindu vienai kitą oponuojančioms partijoms ir organizacijoms, kurias iš esmès vienijo vienintelis tikslas - Kučmos režimo pakeitimas. Taip susiformavo blokas "Mūsų Ukraina“", kurị sudarè dešimt politinių partijų bei organizacijų. Bloko elektorato branduoliu tapo Vakarų ir iš dalies Vidurio Ukraina. Politiniu partijų ir organizacijų spektre blokas „Mūsu Ukraina“ pasistengè „,užimti“" provakarietiškos politinės jègos nišą.

Judèjimo „Mūsų Ukraina“ pozicijos Ukrainos politinèje sistemoje sustiprèjo, kada prie jo prisijungė Julijos Timošenkos vadovaujama politinių partiju koalicija. Ir Juščenka, ir Timošenko buvo išeiviai iš Kučmai artimos valdžios nomenklatūros (Timošenko priklausẻ vienai iš Dnepropetrovsko klano atšaku, kuriai vadovavo Ministro Pirmininko pareigas ejjęs Pavelas Lazarenko). Tačiau vèliau nuo režimo jie nutolo ir galiausiai kovą su Kučma bei vadinama oligarchine valdžios sistema paverte pagrindiniu savo politinès kovos objektu. Šis Juščenkos ir Timošenko aljansas pasirodè labai produktyvus prezidento rinkimų Ukrainoje metu, abu opozicijos lyderiai gerai papildè vienas kitą: Juščenka demonstravo nuosaikesnę, evoliucinę liniją, o J. Timošenka - radikalią ir revoliucinę.

Apskritai kalbant, apie 2004 metų vidurị Ukrainoje aiškiai susiformavo du tarpusavyje konkuruojantys, reprezentuojantys dvi skirtingas šalies raidos vizijas „politiniai blokai“. Pirmasis - valdžiai oponuojantis Juščenkos ir Timošenko tandemas, apie kurị telkėsi „Mūsų Ukraina“ blokas, antrasis telkėsi apie Kučmos remiamą pretendentą i prezidentus Ukrainos vyriausybės vadovą Viktorą Janukovičių ir jo vadovaujamą politinį bloką „Už vieningą Ukrainą". Šio politinio aljanso pagrindą sudarẻ Regionų partija, atstovaujanti Donecko pramonininkų interesams. Juščenka ir jị remiančios politinès jẻgos save reprezentavo daugiau kaip provakarietišką jègą, o Janukovičiaus ir jį remiančios politinès struktūros pasisakè už glaudesnius santykius su Rusija. Paprastai tokių dvieju didelių politinių blokų ar aljansu, kurie deklaruoja priešingas šalies raidos kryptis, susidarymas sparčiai politizuoja bei poliarizuoja visuomenę ir šia prasme formuoja prielaidas ",revoliucinei situacijai" .

Svarbu pastebèti ir tą aplinkybę, jog Ukraina L. Kučmos prezidentavimo laikotarpiu išliko ne tik pliuralistinė, bet ir atvira Vakarų demokratinių struktūrų įtakoms. Ši aplinkybè suvaidino svarbų vaidmenį prezidento rinkimų metu ${ }^{7}$. Prezidento rinkimus, ypač antrojo turo, stebejjo beprecedentis įvairių užsienio demokratinių organizacijų bei institucijų stebėtojų skaičius. Būtent jų rinkimų vertinimas formavo bendrą Vakaru (ES ir JAV) ir pačių ukrainiečių požiūrị i antrojo turo prezidento rinkimus kaip į neskaidrius, nedemokratinius ir falsifikuotus. Galiausia Ukrainoje, pirmiausia didesniuose miestuose, ypač Kijeve, aktyviai veiké pilietinės organizacijos (pvz., „Pora“), kurių pagrindinis tikslas buvo pasipriešinti valdžios siekiams legitimizuoti neteisingus rinkimus.

${ }^{5}$ Karatnycky A., „Ukraine's Orange Revolution“, Foreign Affairs, Mar/Apr, 2005, vol. 84. Issue 2.

${ }^{6}$ Tilly Ch., European Revolutions 1492-1992, Blackwell, 1993, p. 29-51.

${ }^{7}$ Chand K. V., „Democratisation from the outside in: NGO and international efforts to promote open elections", Third World Quarterly, vol. 18, no. 3, 1997, p. 543-550. 


\subsubsection{Oligarchinès politikos ypatybès}

Analizuojant Ukrainos politinès sistemos ypatybes, jai būdingą „,demokratijos deficitą", dažnai teigiama, jog demokratijos „stygių“" sąlygoja ir tiesioginis stambių verslofinansinių arba dar kitaip vadinamų oligarchinių grupių suaugimas su politine valdžia. Plačiau nediskutuodami su šia prielaida, pastebèsime, jog apie 2000 metus išryškëjo oligarchinès sistemos krizè, ,,atvedusi“ šali prie revoliucinės režimo transformacijos.

Paprastai Ukrainoje skiriamos kelios stambiausios dèl įtakos aukščiausiai politinei valdžiai tarpusavyje besivaržančios "oligarchinès grupès“. Tai Dniepropetrovsko grupè (jai priklauso L. Kučmos žentas Viktoras Pinčukas), Kijevo grupe (šios grupès įtakingiausiu atstovas Viktoras Medvečiukas buvo ir L. Kučmos administracijos vadovas), Donecko grupè, kuriai vadovavo Rinatas Achmetovas, buvo glaudžiai susijusi su V. Janukovičiumi.

Be šių stambiausių oligarchiniu grupiu, Ukrainoje egzistavo ir daug daugiau smulkesnių ekonominiu ir politiniu požiūriu ne tokių įtakingų grupių bei neformaliu susivienijimų. Bendras Ukrainos ekonomikos augimas sudarè prielaidas tokių smulkesnių grupių formavimuisi ${ }^{8}$. Pradžioje šiu grupių poveikis labiau reiškèsi regionuose. Pavyzdžiui, vienas iš pagrindinių finansinių V. Juščenkos rèmëju Piotras Porošenko stiprias ekonomines bei politines pozicijas turëjo vakarinëje Ukrainos dalyje. Sustiprinusios savo poveikį regionuose, tokios grupės bei jų lyderiai darèsi nepatenkinti „uždara“ oligarchine sistema, kuri vis labiau trukdè jų verslo ir politinès įtakos plètrai. Prezidento rinkimai tokioms grupėms sudarè „politinę galimybę“ išsikovoti daugiau įtakos politinės sistemos centre, o tai turëjo atverti naujas galimybes ir jų verslo plètrai.

Dar vienas oligarchinės sistemos krizės požymis buvo susijęs su prezidento vaidmens pokyčiu. Ukrainos oligarchinèje sistemoje prezidentas de facto atliko interesų tarp skirtingų grupių derintojo arba tarpininko vaidmenį. Kučmai iki 2000 metu pradžios pavykdavo vykdyti šias funkcijas, jis buvo ir pakankamai aktyvus, ir stiprus prezidentas, sugebantis bent jau formaliai išlaikyti tam tikrą distanciją nuo oligarchiniu grupių. Tačiau apie 2000-2001 metus prezidento prestižas, pasitikèjimas juo smuko, o drauge sumažèjo ir jo faktinė galia. Taip atsitiko dèl politinių skandalų (G. Gongadzès nužudymas) bei praktiškai visiškai neskaidrios privatizacijos, kuri kèlè smulkesnių verslo grupių bei apskritai visuomenès nepasitenkinimą. Taigi oligarchinè sistema, paremta prezidento balansavimu tarp stambiausiu verslo grupiu, ižžengẻ ị kritinę stadiją. (2004 metais L. Kučmos populiarumas visiškai smuko, juo pasitikejo tik apie 3 proc. gyventoju.)

Siekdamas saugumo, pirmiausia savo interesų apsaugojimo, Kučma buvo priverstas vis labiau šlietis prie vienos oligarchinés grupès, tuo tik dar labiau didindamas visuomenés nepasitenkinimą ir spaudimą. Visuomenės kritikos ir nepasitenkinimo objektu tapo jau ne vien tik prezidento asmuo, viena ar kita

82002 m. Ukrainos BVP išaugo 5,2 proc., 2003 m. jau 9,4 proc., o 2004 m. - 12,5 proc. Apskritai nuo 1999 m. iki 2004 m. Ukrainos BVP padvigubëjo žr. Karatnycky (5 išnaša) p. 87. 
oligarchų grupè, bet visa sistema. Šia situacija opozicinės jegos gerai pasinaudojo, save pateikdamos kaip kovotojus su korumpuota "oligarchine“ politine bei ekonomine sistema.

\subsubsection{Regionalizacija ir politika}

Prezidento rinkimų eiga parodė, jog šalies regioninė specifika, Ukrainos regionu geopolitinė orientacija ir gravitacija aiškiai veikia rinkëju pasirinkimą ir elgesį. Per visus tris prezidento rinkimų turus Juščenka didžiausios paramos susilaukdavo vakariniuose Ukrainos regionuose, o Janukovičius - rytiniuose ir pietiniuose ${ }^{9}$. Todèl, mūsų manymu, ne mažiau svarbus sẻkmingai revoliucijai (geopolitiniu požiūriu suvaidinęs tikriausiai lemiamą vaidmenį) buvo tas faktas, jog Juščenka ir jo rèmejjai nugalëjo centriniame Kijevo regione ir pačioje šalies sostineje. Palyginimui pateiksime kelis duomenis: Jušenka Kijevo regione per tris rinkimu turus atitinkamai surinko $59,72,76,36,82,70$ proc. rinkèju balsu, o pačiame Kijevo mieste - atitinkamai $62,3,74,36,78,37$ proc. ${ }^{10}$ Ši aplinkybé padèjo opozicijai ne tik greitai mobilizuoti savo rèmejjus bei vykdyti masinę pasipriešinimo akciją, bet ir buvo netikèta Janukovičiui, kuris šalies sostinëje praktiškai atsidūrè visiškoje izoliacijoje, negalëjo ne tik efektyviai vykdyti savo funkciju, bet ir telkti savo rèmëjų.

\subsection{Oranžinè revoliucija ir geopolitika}

Vis dèlto aiškinant politinės krizės Ukrainoje atomazgą, pabrěžiama išoriniu veiksniu ìtaka arba pažymimos geopolitinès Oranžinès revoliucijos priežastys. Pirmiausia teigiama, jog Ukraina, atsidūrusi ypatingoje Vakaru ir Rusijos geopolitiniu interesu sankirtoje, buvo veikiama tiek Vakaru, tiek Rusijos poveikio ir „dalyvavimo" rinkimuose. Vakarai, pirmiausia JAV, ir Rusija turëjo savo palaikomus kandidatus. Vakarai pasirodè efektyviau, todèl ir nugalëjo, taip pat sustiprino savo įtaką vakarinëje NVS dalyje ir sudavė rimtą smūgị V. Putino regioninėms ambicijoms. Remiantis tokia geopolitine logika, Rusijoje Juščenkos išrinkimas dažnai buvo interpretuojamas kaip Vakaru gerai suplanuota ir atlikta „,speciali operacija“11.

Net ir nesutinkant su tokiais sąmokslo teorijos logikai būdingais samprotavimais, tektu pripažinti, jog išorés poveikis arba paaštrëjusi konkurencija Ukrainoje tarp Vakaru ir Rusijos buvo svarbus veiksnys, kuris veikė politinę krizę Ukrainoje bei jos atomazgą. Manytume, kad taip atsitiko dèl kelių pagrindiniu

\footnotetext{
${ }^{9}$ Ukrainos vyriausios rinkimu komisijos duomenys. Žr. www.cvk.gov.ua/pls/vp2004/ wp0011, 20050214

10 Ten pat.

${ }^{11}$ Turbakov I., „Wanted: Compatative Ideology and Attractive Social Model to Help Russia Retain its Crumbling Sphere of Influence", Eurasia Daily Monitor, vol. 2. Issue 10, (January 14) 2005; Жовер В., „Творцы революций“, www.archipelag.ru 200505 27; Шайхудинов Р., ,Демократия в условиях спецоперации: как убить государство“, www.archipelag.ru 20050527.
} 
priežasčiu . Pirma, Vakarai (labiau JAV) ir Rusija prezidento rinkimus Ukrainoje įvertino kaip strategiškai reikšmingus, t. y. galinčius nulemti tolesnę šalies geopolitinę orientaciją. Antra, Ukrainos atžvilgiu svarbiausi „išoriniai veikejjai“ (JAV, ES bei Rusija) laikèsi skirtingu politiniu liniju. V. Putinas, pasinaudodamas rinkimais, siekè tiesiogiai sustiprinti Rusijos įtaką Ukrainoje, o Vakarai paspartinti demokratizacijos procesus Ukrainoje ir taip plèsti savo įtaką. Trečia, reikia turèti galvoje, jog vadinamasis Vakarų struktūrų ir Rusijos interesų persidengimas NVS erdvëje yra dinaminis procesas, kuris suponuoja nuolatinę konkurenciją. Tiesa, ši dẻl abipusio suinteresuotumo neperauga į tiesioginius konfliktus. Tai reiškia, jog ir Vakarai, ir Rusija, pasinaudodamos vidine politine šalių konjunktūra, stengiasi (ir stengsis) konkuruoti juose dèl įtakos.

\subsubsection{Putino Ukrainos projektas}

Galima teigti, jog Kremlius prezidento rinkimus Ukrainoje stengèsi išnaudoti kaip priemonę, konsoliduojant Rusijos įtaką Ukrainoje ir paspartinant Vieningos ekonominės erdvės (VEE) struktūros formavimąsi. Tokios struktūros sukūrimas būtų sustiprinęs Maskvos pozicijas ne tik posovietinëje NVS erdvèje, bet, kas dar svarbiau, būtu pakèlęs ir tarptautinį Putino prestižą.

O štai Kazachstano, ar tuo labiau Baltarusijos, požiūris į Rusijos formuojamą VEE projektą buvo iš esmès teigiamas, oficialusis Kijevas ilgą laiką dvejojo ir laviravo, tikèdamasis išgauti nuolaidų iš Vakarų. Tačiau jau 2003 metų L. Kučma suaktyvino savo bendradarbiavimą VEE organizacijoje. Bendradarbiavimas VEE numatė ir bendrų politinių struktūrų kūrimą. Akivaizdu, jog ekonominès ir menamas politinès integracijos gilinimas galiausiai būtų izoliavęs Ukrainą nuo Vakarų struktūrų.

Prieš rinkimus atrodè, jog Maskvos skaičiavimai dèl jai palankios prezidento rinkimų kampanijos baigties turi labai rimtą politini, ekonominį bei socialinį pagrindą. Ukrainoje egzistavo stiprios verslo grupės bei politinės jėgos, turinčios glaudžius santykius su Rusija, žymi Ukrainos gyventojų dalis prioritetu laikè santykius su Rusija arba su „,slaviškų valstybių sajunga“. Kremlius turëjo geras informacines bei finansines galimybes veikti rinkimų procesą ir galiausiai 2004 metų rudenį asmeninis Vladimiro Putino populiarumas Ukrainoje buvo išties didelis (jis buvo laikomas pačiu populiariausiu politiku ${ }^{12}$ ). Kremliaus požiūriu, įtakai Ukrainoje plètoti susidarė palanki ir tarptautinè situacija: JAV buvo užsièmusios prezidento rinkimais bei karu Irake, o ES - naujų narių integracija ir Konstitucijos prièmimo klausimu.

İvertindamas strateginę rinkimų reikšmę bei turimus resursus, Kremlius pasirinko pakankamai paprastą politinę liniją - paremti vieną parankesnį pretendentą. Kandidatas i prezidentus Janukovičius savo programinėse kalbose žadëjo atsisakyti Ukrainos siekio tapti NATO nare, siūlè rusų kalbai suteikti valstybinės kalbos statusą bei įvesti dvigubą pilietybę ${ }^{13}$. Neslepiamą palanku-

\footnotetext{
12 Trenin (4 išnaša) p. 2. Мошес А., „Двойное расширение и российско-украинские отношения“, Московский центр Карнеги. Между Востоком и Западом. Украина и Белорусия на Европейском пространстве, Москва, 2003, с. 12-16.

13 „Украина выбирает президента и место на карте мира“, www.korespondent.ua 20041004
} 
mą šiam kandidatui èmé demonstruoti oficiali Rusijos žiniasklaida. Savo paramą pretendentui asmeniškai parodė ir pats Rusijos prezidentas, nes bent du kartus apsilankẻ Kijeve bei bendravo tik su Janukovičiumi (vèliau, po antrojo turo, V. Putinas jị netgi pasveikino su pergale, nors oficialūs prezidento rinkimu rezultatai dar nebuvo paskelbti $\left.{ }^{14}\right)$. Kartu Rusija atmetė bendradarbiavimo su Juščenka galimybę. (Teigiama, jog dar 2004 metų pavasarị Juščenkos aplinka bandè užmegzti asmeninius kontaktus su V. Putinu, tačiau Kremlius į iniciatyvą neatsake $\dot{e}^{15}$. Tam įtakos, matyt, turëjo ta aplinkybè, jog Maskva V. Juščenką suvokè kaip Vakaru palaikomą kandidatą.)

Todèl visiškai suprantama, jog Juščenkos pergalè Maskvoje buvo interpretuota kaip strateginis, geopolitinis ir pagaliau paties Rusijos prezidento Vladimiro Putino pralaimëjimas. Pirma, iškilo reali grèsmė Rusijos proteguojamam VEE projektui, o kartu ir Maskvos dominavimui NVS erdveje. Antra, prezidento rinkimų kampanija Ukrainoje ir jos baigtis parodė, jog Rusijos įtaka NVS regione ir toliau silpnèja. Kitaip tariant, Kremliaus pasiūlytas naujas NVS šaliu integracijos modelis (VEE) neatlaiko konkurencijos su Vakarų siūlomomis bendradarbiavimo formomis. Trečia, politinè krizė Ukrainoje pademonstravo Kremliaus ir asmeniškai paties Rusijos prezidento nekompetenciją. Nors ir, atrodytu, turèdama daug palankesnes aplinkybes veikti Ukrainoje, Maskva jomis taip ir nesugebejo deramai pasinaudoti. Galiausiai Putinas buvo priverstas trauktis ir sutiko su Vakarų pasiūlytų krizès sureguliavimo scenarijumi - surengti pakartotinius antrojo turo balsavimus.

\subsubsection{Vakarai ir Ukrainos demokratizacijos projektas}

Iš esmès Vakarai (labiau JAV nei ES) taip pat vertino rinkimus kaip strateginius, t. y. galinčius turèti įtakos ne tik Ukrainos valstybès raidos perspektyvoms ar Rusijos dominavimui NVS regione, bet apskritai Vakaru - Rusijos santykiams. Manytume, jog Vakarus (pirmiausia JAV) gąsdino ne tik Kremliaus siekiai stiprinti savo įtaką Ukrainoje ar konsoliduoti dominavimą NVS, bet ir pokyčiai Rusijos vidaus politikoje. Putino pastangos didinti prezidento galias, stiprinti ,"valdžios vertikalę“ Vakaruose vis dažniau buvo vertinamos kaip atsitraukimas nuo demokratijos. Vakaru, pirmiausia JAV, taip pat naujujų ES nariu požiūriu tokios vidinès Rusijos tendencijos bei Maskvos siekiai sustiprinti savo įtaką Ukrainoje reiškè ne ką kita, bet Kremliaus bandymą atkurti savo dominavimą visame Vidurio Rytų Europos regione. Vašingtono vertinimu, tokių tendencijų plètotè destabilizuotų situaciją tarp naujujų ES bei NATO narių, o tai keltų grèsmę ne vien tik euroatlantiniams ryšiams, bet ir galètu gerokai sustiprinti kontinento įsivyravimo tendencijas Europoje.

Šalia strateginių ir geopolitinių argumentų, formavusių požiūrị ị rinkimus Ukrainoje, egzistavo ir ideologinis imperatyvas - posovietinės erdvés demokratizacija. Demokratijos įtvirtinimas ne tik prisidètų prie Ukrainos stabili-

${ }^{14}$ Zarakhovich P., Calabresi Y., etc. "The Orange Revolution", Time, 06122004.

${ }^{15}$ Trenin (4 išnaša ) p. 2. 
zacijos ir taip sudarytų prielaidas jos integracijai su Vakarų struktūromis, bet ir apskritai turètų teigiamą, stabilizuojantị poveikį visam Vidurio Rytų Europos regionui.

Todèl visiškai suprantama, kodèl Vašingtonas nepaisydamas Irako krizès „,isitraukè “ i prezidento rinkimus Ukrainoje. Tiesa, formaliai George W. Busho administracija nepalaikè nè vieno kandidato (neformaliai - Juščenką), o pasisakẻ už skaidriu, teisingų ir demokratinių rinkimų organizavimą, tikèdamiesi, jog tokių rinkimų atvejų turètų laimèti Juščenka. Anot JAV Valstybės departamento ataskaitų Kongresui, būtent tokios strategijos Vašingtonas laikèsi jau nuo pat 2004 metų pradžios. Pagrindinè finansinè parama buvo skiriama nevyriausybinei žiniasklaidai, įvairioms Ukrainos nevyriausybinėms organizacijoms, kurios kaip tik ir turëjo užtikrinti rinkimų skaidrumą. Daug lěšų Vašingtonas tiesiogiai skyrè stebėtojų išlaikymui. Beje, didžioji dalis amerikiečiu paramos apskritai buvo skiriama iš ir per įvairius nevyriausybinius fondus bei organizacijas, kurių pagrindinis uždavinys buvo skatinti demokratijos plètrą posovietinèje erdveje. Valstybės departamento teigimu, tokiems tikslams 2004 metais buvo skirta apie $13,8 \mathrm{mln}$. dolerių ${ }^{16}$.

Artëjant rinkimams, JAV ėmė vis aktyviau spausti oficialų Kijevą, jog būtų užtikrinti teisingi rinkimai. 2004 metų spalio mèn. pradžioje Bendruomenių rūmai prièmè specialią Ukrainos rinkimų rezoliuciją, reikalavusią, jog oficialus Kijevas užtikrintų teisingus ir sąžiningus rinkimus ${ }^{17}$. Spalio viduryje ir lapkričio mèn. jau Valstybės departamentas padarẻ kelis pareiškimus dẻl rinkimu Ukrainoje, perspėdamas Ukrainos valdžią dèl pasekmių už rinkimų pažeidimus. Specialiai rinkimams stebèti Baltieji rūmai siuntė i Kijevą senatorių Richardą Lugarą. Beje, senatorius po antrojo rinkimų turo (lapkričio 22 d.) pareiškè, jog Ukrainos valdžia įsivèlusi ị rinkimų rezultatų klastojimą ir nesistengé užtikrinti sąžiningų rinkimų. Pagaliau lapkričio $25 \mathrm{~d}$. JAV Valstybès sekretorius Collinas Powellas, remdamasis ịvairiu tarptautinių (pirmiausia ESBO misija) bei nevyriausybinių organizaciju, stebëjusių rinkimus ir užfiksavusių gausybę pažeidimu, išvadomis, pareiškè, jog Vašingtonas nepripažins rinkimu Ukrainoje rezultatų. Tą pačią dieną pareiškimą padarẻ ir ES, tiesa, gerokai švelnesni. Anot tuo metu ES pirmininkavusio Olandijos premjero Jan Peter Balkenendès, prezidento rinkimai neatspindëjo ukrainiečiu troškimų.

Prasidejjus masinėms Juččenkos rẻmëju protesto akcijoms, Vašingtonas ir toliau spaudė oficialu Kijevą, perspėdamas nenaudoti jègos prieš protestuotojus, pradėti derybas su opozicija bei ragino organizuoti tikrus, demokratinius rinkimus. ES laikèsi iš esmès tų pačių nuostatu (Balkenendè gruodžio $1 \mathrm{~d}$. Putinui pakartojo tuos pačius reikalavimus, kaip ir Vašingtonas). Neabejotina, jog toks $\mathrm{p} E S$ ir JAV pozicijų bendrumas iš principo privertė Ukrainos valdžią ieškoti kompromisinių politinių sprendimų ir derètis su opozicija. Galiausiai gruo-

${ }^{16}$ Tefft J., Deputy Assistant Secretary for European and Eurasian Affairs. Testimony Before the House International Relations Committee, December 7, 2004.

17 "The German Marshall Fund of US in co-operation with Center for Europon and International Studies, Kiev", Ukraine and the Euro-Atlantic Community: Strategy Dialogue. Summary Report of the First Session Kiev, 24-2609 2004. 
džio 3 d. Ukrainos Aukščiausias Teismas panaikino Vyriausios rinkiminės komisijos sprendimą dèl Janukovičiaus pergalès ir paskelbè, jog bus dar kartą surengtas antrasis prezidento rinkimų turas. Būtent to ir reikalavo opozicija. Tokị teismo sprendimą pasveikino ir Vašingtonas. Gruodžio $26 \mathrm{~d}$. surengti pakartotini prezidento rinkimai, kuriuos stebëjo apie 12 tūkst. stebėtojų. V. Juščenka surinko 52 proc. balsu, o Janukovičius - 44 procentus. Juščenka laimëjo 17 regionu, vakaruose ir centrinèje Ukrainoje, o Janukovičius - 10 pietu ir rytų regionų.

\subsubsection{Regioniniai veikèjai: Lenkijos ir Lietuvos tandemas}

Nors Vakarai ir sutiko, jog krizę Ukrainoje būtina sureguliuoti politinèmis, taikiomis priemonėmis, tačiau konkretų sprendima, kaip sureguliuoti politinę situaciją, pasiūlè naujieji ES nariai ir Ukrainos kaimynai - Lenkija bei ją parèmusi Lietuva. Pažymėtina, jog pradžioje Briuselis nerodė didesnio entuziazmo tiesiogiai ịsitraukti ị krizès reguliavimą. (Tyrinètojai netgi pastebi, jog formalūs ES užsienio politikos „mechanizmai savo vaidmens krizės sureguliavime neatliko": ES „Troika“ šiame procese visai nedalyvavo, o pirmininkavusi Olandija vaidino antraeilį vaidmenị ${ }^{18}$.) Chavjeras Solana tik po ilgų Varšuvos ịtikinejjimų sutiko užklausti kai kurių ES šalių lyderių apie ju požiūrį dẻl Europos Sajungos misijos pasiuntimo į Ukrainą. Atrodo, jog Vokietijos kancleris tokiai idèjai santūriai pritarè, Prancūzijos prezidento požiūris buvo skeptiškesnis. Tačiau Lenkijos iniciatyvą parėmė Vašingtonas ${ }^{19}$. Naujujų ES bei NATO nariu (Lenkijos, kurią rėmè Lietuva) iniciatyva ir dalyvavimas krizės reguliavime buvo svarbus keletu aspektų. Pirma, užsienio tarpininkų dalyvavimas (be Lenkijos prezidento Kwasniewskio, Lietuvos prezidento Adamkaus, tarpininkavimo misiją atliko Solana bei Rusijos Dūmos pirmininkas Gryzlovas) sustiprino įsitikinimą, jog politinę krizę galima išspręsti taikiai, be kraujo praliejimo. Antra, Lenkijos ir Lietuvos aktyvumas ir iniciatyvumas parodè, jog naujieji ES nariai gali praktiškai pasitarnauti Europos Sajungos rytu politikai. Galiausiai trečia, užsienio tarpininkavimas dar kartą pademonstravo ribotas Rusijos galimybes, sprendžiant politinius konfliktus NVS erdvëje.

Varšuvos ir Vilniaus pasiūlytas politinio konflikto sureguliavimo planas (jam galiausiai pritare ir kiti tarpininkai) buvo kompromisinis, derinantis abieju konfliktuojančiu pusių interesus: organizuoti pakartotinius antrojo turo prezidento rinkimus bei padaryti pakeitimus rinkimu istatyme. Tuo pat metu sutarta ir dèl politinės reformos principu. Numatomos politinès reformos nuostata iš esmės buvo sumažinti prezidento galias ir įtaką politinëje Ukrainos sistemos bei sustiprinti parlamento ir vyriausybės vadovo galias. Tokie pasiūlymai tenkino ir Janukovičiu, ir Juščenka, taip pat dejjo pagrindus Ukrainos politinès sistemos demokratizacijai (Politinè reforma turètų isigalioti po 2006 metų kovo mèn. Rados rinkimų).

${ }^{18}$ Gromadzki G., Sushko O., Vahl M., Wolczuk K., Wolczuk R., Will the Orange revolution bear fruit? EU-Ukrainian relations in 2005 and the beginning of 2006. Stefan Batory Foundation, Warsaw, 2005, p. 15.

${ }^{19}$ Босацкий М., Войцеховский М. „Закулисная история революции“, http:/ /www.inosmi.ru/translation/218911/html 15042005. 


\section{Po „Oranžinès revoliucijos“: naujos užsienio politikos perspektyvos}

Literatūroje, analizuojančioje Ukrainos saugumo bei užsienio politiką, paprastai pažymima, jog Juščenkos pergalẻ formavo prielaidą labiau provakarietiškai Ukrainos užsienio politikai ${ }^{20}$. Tokias analitikų prielaidas stengèsi patvirtinti ir pats naujasis Ukrainos prezidentas. 2005 metu sausio $26 \mathrm{~d}$. būdamas Strasbourge ir kalbėdamas ET Parlamentinèje Asamblèjoje Juščenka pabrèžè, jog pagrindinis šalies užsienio politikos tikslas - įstoti į ES. Briuselyje NATO viršūnių susitikime vasario $22 \mathrm{~d}$. jis pareiškè, jog Ukrainos užsienio politika turi du prioritetus - integruotis ir į ES, ir į NATO. Tačiau tokios politinès linijos igyvendinimas susijęs su keliomis dilemomis.

Pirma. Ukrainos siekis spartinti integraciją i Vakarus gali sukelti įtampą Rytuose. Kitaip tariant, Kijevas, vykdydamas integracijos į Vakarus politiką, neišvengiamai paaštrintų santykius su Rusija, o santykių su Maskva paaštrëjimas gali blokuoti provakarietišką Kijevo politiką. Antra. Vakarų struktūros nei politiškai, nei ideologiškai nèra pasiruošusios Ukrainai pasiūlyti spartesnio integracijos plano. Tam įtakos turi vidinis Vakarų neapsisprendimas, nenoras aštrinti santykių su Maskva ir galiausiai objektyvus Ukrainos nepasiruošimas integruotis. Kitaip tariant, ir po "Oranžinès revoliucijos" Kijevui teks dar pakankamai ilgą laiką susidurti su Vakarams būdinga inercija Ukrainos atžvilgiu. Ši aplinkybė gali susilpninti Ukrainos visuomenės paramą provakarietiškai naujos valdžios orientacijai, o valdžios elitą pastūmèti link ,"daugiavektorinės politikos", kuri buvo būdinga Kučmos laikotarpiui. (Beje, sociologinės apklausos rodo, kad visuomenės parama, pavyzdžiui, šalies narystei NATO išlieka pakankamai maža ${ }^{21}$.)

Manytume, jog naujos Ukrainos valdžios gebėjimas spręsti šias dilemas priklausys nuo vidinių ir išorinių aplinkybių.

Vidiniu - ar V. Juščenkos ir J. Timošenkos blokas sugebės konsoliduoti politines jègas ir laimèti rinkimus į Aukščiausią Radą 2006 metais. Provakarietiškų ir demokratiniu jègų pergalè būtų signalas Vakarams, jog bus vykdomos politinės bei ekonominès reformos. Kartu tai reikštų ir provakarietiško užsienio politikos kurso tęstinumą.

Išorinių - kokios pozicijų naujos Ukrainos valdžios ir jos vykdomos politikos atžvilgiu laikysis Maskva ir Vakarai.

\footnotetext{
${ }^{20}$ Kuzio T., „From Kuchma to Yushchenko. Ukraine's 2004 Presidential Elections and the Orange Revolution", Problems of Post-Communism, vol. 52, no.2, March/April 2005, p. 2942.

${ }^{21}$ Shamsur O., "Ukraine between the Major International Players“, roundtable seminar "Neigbours or Relatives?" organized by the Finnish Institute of International Affairs in co-operation with the Embassy of Finland in Ukraine, Kiev, 0426 2005. Apskritai visos Ukrainos mastu gyventoju parama NATO nesiekia nė 20 proc. Štai pvz., 2005 metu pradžioje atliktu apklausų duomenimis tik 15 proc. Ukrainos gyventoju pasisako už šalies prisijungimą prie Aljanso, o 48 proc. - griežtai prieš. Žr. Gorska A., "NATO mowi "tak" Ukraine“, Osrodek Studiow Wschodnich. Komentarze, Warszawa, www.osw.pl 20051027.
} 


\subsection{Rugsèjo vyriausybès krizè ir nauja politinè situacija šalyje}

Deja, jau 2005 metų rugsẻjo mėn. Juščenkos ir Timošenkos tandemas subyrëjo. Rugsëjo pradžioje vyriausybės vadovès šalininkai apkaltino Prezidentui Juščenkai artimus politikus (pirmiausia Piotrą Porošenką) korupcija. Galiausiai prezidentas nutare atstatydinti Timošenkos vyriausybę ir atsisveikinti su keliais savo politiniais bendražygiais. Taigi Timošenkos politinis blokas perèjo i̇ opoziciją prezidentui. Ši aplinkybė tik dar labiau pagilino politinę krizę šalyje. Naujaji vyriausybės vadovą Juriju Jechanurovą Rada patvirtino tik rugsejjo $22 \mathrm{~d}$. Jechanurovas buvo patvirtintas tik po to, kai jo kandidatūrą parėmè Regionu partija, vadovaujama Janukovičiaus. (Pirmą kartą Jechanurovui pritrūko deputatų balsu.) Siekdamas išbristi iš politinès krizès ir suformuoti vyriausybę, Juščenka pasirašè su Janukovičiumi susitarimą, kuriuo naujoji valdžia įsipareigojo teisiškai nepersekioti Janukovičiaus rẻmëju. Toks paktas leido suformuoti vyriausybę ir drauge stabilizavo situacija šalyje, tačiau kartu ir suskaldè oranžinės revoliucijos rèmèju gretas. Iš esmès tapo aišku, jog i Rados rinkimus $2006 \mathrm{~m}$. kovo mèn. pavasarį Juščenka ir Timošenka eis atskirais politiniais blokais. Ši aplinkybė padidina Janukovičiaus perpektyvas laimėti Rados rinkimuose. Tiesa, atotrūkiai tarp pagrindinių politiniu jègų būsimoje Radoje neturètų būti dideli, o tai gali apsunkinti stabilios vyriausybès formavimą ${ }^{22}$. Galima spèti, jog aiškios daugumos neturinti ir nestabili vyriausybè negalès vykdyti nei būtinu, tačiau dažnai skausmingų ekonominių - socialinių refor$\mathrm{mu}$, nei kelti ambicingu provakarietiškos integracijos projektu.

Galima teigti, jog Oranžinès revoliucijos nugalètojai nesugebėjo efektyviai pasinaudoti savo pergale. Ju kalbos dažnai skirdavosi nuo darbų. Šalyje praktiškai nebuvo vykdomos struktūrinès reformos, nepakankamai efektyviai kovota su korupcija, nevyko administracinè, teismų reformos, dèl nuolatinių ir prieštaringų valdžios atstovų pareiškimų apie reprivatizaciją pablogèjo šalies investicinis klimatas, vyriausybè nevykde savo pažadų pagrindiniam Oranžinès revoliucijos rèmëjui - smulkiam ir vidutiniam verslui. Iš esmès Timošenkos vyriausybė tęsė savo pirmtako Janukovičiaus politiką: šis prieš prezidento rinkimus didino pensijas, o Timošenko net 57 proc. sugalvojo padidinti algas biudžetininkams. Apskritai jos pasirinkta ekonominè politika analitikų vertinta kaip „socialistinè ir populistinè “23. Tokios politikos rezultatai netruko pasi-

\footnotetext{
${ }^{22}$ Apklausos rodo, jog didžiausias galimybes laimèti būsimus Rados rinkimus turi Regionu partija vadovaujama Janukovičiaus. Už ją balsuotų apie 20 proc. rinkejjų. "Mūsų Ukraina”, kurios garbės pirmininkas yra Juščenka, surinktų 12,5 proc. balsų. Maždaug tiek pat balsų gautų ir Timošenkos vadovaujamas blokas. Iš viso 3 procentų barjerą gali tikètis įveikti dar trys partijos: Simoneneko vadovaujama Komunistų - 6,2 proc., Morozo Socialistų - 5,7 proc. bei Rados pirmininko Vladimiro Litvino vadovaujama Liaudies partija - 3,4 proc. Sociologinę apklausą atliko nepriklausomas Ekonominių ir politinių tyrimų Razumkovo centras, kuomet šalis išgyveno vyriausybinę krizę. Žr ,,?прос: на выборох в ближайшее времья победила бы Партия регионов“, www.korrespondent.net 20051020.

${ }^{23}$ Аслунд А., „Предательство революции“, http: / / www.inosmi.ru/translation/222224.html, 2005 05 18; Кохен А., „Украине пора пересмотреть свою экономическую политику“, http: / / www.inosmi.ru/translation/222224.html, 200508 16; D“ Anieri P., „What Has Changed in Ukrainian politics? Assessing the implications of Orange Revolution", Problems of Post-Communism, vol. 52, no. 5, September/October 2005, p. 82-91.
} 
reikšti - ėmė smarkiai blogèti šalies ekonominė padètis. Štai 2004 metais BVP augimas sudarė 12 proc., 2005 metų pavasarị BVP sumažèjo iki 5 proc., infliacija išaugo 15 proc. 2005 metų rudenị BVP augimas sumažèjo iki 3,7 procento ${ }^{24}$. Ekonominis smukimas pastebimas įvairiose šakose nuo žemès ūkyje iki statybų. Šalies ekonomiką krètè naftos, mėsos, cukraus ir panašios „krizès“. Neigiami socialiniai - ekonominiai procesai mažina pasitikèjimą Juščenka ir jo naujuoju premjeru. (Apklausų duomenys rodo, kad apie 50 proc. ukrainiečių mano, jog ju gyvenimo sąlygos išrinkus Juščenką prezidentu pablogèjo, ir tik 11,5 proc. mano, kad pagerejjo ${ }^{25}$.) Mažai tikètina, jog naujajam vyriausybès vadovui pavyktu iš esmès pakeisti šalies ekonomines bei socialines tendencijas šalyje, o tai reiškia, kad jẻgos, siekiančios revanšo už pralaimëjimą 2004 metu prezidento rinkimuose, turi tam pakankamai geras sąlygas. Tiesa, ar joms pavyks didelès visuomenès dalies nepasitenkinimą savo socialine bei ekonomine padètimi paversti politiniu kapitalu, kol kas nèra aišku. Juolab jog ir ekonominëje Ukrainos padangejje atsirado tam tikrų optimizmo ženklų. Naujai valdžiai efektyviai ir skaidriai pavyko užbaigti "Krivojrižstal“ reprivatizacijos bylą: užsienio investuotojas už šią gamyklą sumokèjo įspūdingą kainą - $24 \mathrm{mlj}$. grivenų arba $4,8 \mathrm{mlj}$. JAV dol. (Priminsime, jog Ukrainos biudžeto ịplaukos 2004 metais buvo lygios $70 \mathrm{mlj}$. grivenu.)

Apibendrindami galime teigti, jog, skilus Juščenkos ir Timošenkos koalicijai, politinè situacija Ukrainoje komplikavosi. Iš esmès visų pagrindinių politinių grupuočių galimybės kovo mèn. Rados rinkimuose išsilygino.

\subsection{Ukrainos ir Rusijos santykių perspektyvos}

Maždaug iki 2005 metų pavasario atrodė, jog Kremlius santykiuose su Ukraina laikysis nuosaikios politinės linijos. Ši strategija remiasi prielaida, jog Kijevo integracija į Vakarų struktūras bent jau artimiausiu metu yra mažai tikètina, o Rusijos ekonominès, socialinès, kultūrinės pozicijos Ukrainoje, nepaisant Juščenkos deklaruojamo provakarietiško kurso, išlieka pakankamai stiprios. Todèl Maskvai netikslinga būtų eskaluoti politinę situaciją Ukrainoje. Priešingai, reikètų stengtis palaikyti gerus kaimyninius santykius, o tai galiausiai sustiprintų ir politinius Maskvos bei Kijevo ryšius.

Ši tendencija išryškejjo tuoj po politinès krizès, pirmojo Putino ir Juščenkos susitikimo metu 2005 metų sausio 24 d. Maskvoje. Susitikimas parodė, jog Kremlius (beje, kaip ir Kijevas) nesuinteresuotas santykių eskalavimu. Susitikimo metu šalys sutarė tęsti ekonomini bendradarbiavimą bei politinį dialogą. Tokią politinę liniją pratęsè ir Putino vizitas į Kijevą kovo 19 d. Jo metu Rusijos prezidentas pareiškè, jog Maskvai ir Kijevui būtina „panaikinti tarp šalių egzistuojančias problemas“ (originaliai ši frazė nuskambëjo įspūdingiau - „začistit problemy“ ${ }^{\prime 2}{ }^{26}$. V. Putinui svarbu buvo išsiaiškinti Ukrainos dalyvavimo VEE

${ }^{24}$ Найденов В., „Чюда не будет“, http://www.grani.kiev.ua/exp.php?ni=3867\&type $=1 \&$ PHPSESSID=311b2aa26bd68f3306676120da54b159 20050901 .

25 „ППочти половина украйнцев щитает, что при Ющенко они стали жить хуже“, www.rosbalt.ru, 2005 1020.

${ }^{26}$ „Путин „зачистит“ российско-украинские проблемы“, Известия, 20050321. 
perspektyvas, o V. Juščenkai - ar Rusija pasirengusi kurti laisvos prekybos zoną. Konkrečių susitarimų minètais dvišaliais klausimais nebuvo pasiekta. Tiesa, Kijevas ir Maskva sutare vietoj komisijos tarp vyriausybių sukurti „Putino Juščenkos" komisiją, kurią sudarytų keturi komitetai: gynybos, tarptautinio bendradarbiavimo, ekonominio bendradarbiavimo ir humanitariniu klausimu ${ }^{\prime 22}$.

Oficialusis Kijevas, siekdama užsitikrinti dalies (ypač į Rusiją orientuoto) elektorato paramą bei nenorédamas pabloginti ir taip ganètinai komplikuotu santykių su Maskva, VEE atžvilgiu vykdè „pragmatinę“ politiką (Vakaruose, beje, manyta, kad po Oranžinès revoliucijos Ukrainos valdžia viešai deklaruos apie savo atsisakymą dalyvauti VEE veikloje). Juščenka neatsisakė dalyvauti VEE veikloje, tačiau savo dalyvavimą stengèsi visaip riboti. Naujos valdžios apsisprendimui išlaikyti ribotą ryši su VEE įtakos turëjo ir ta aplinkybė, jog naujoje Ukrainos valdžioje yra politiku, kurių verslo interesai glaudžiai susiję su VEE erdve. Palaikydami idejją, jog Ukrainai reikia dalyvauti VEE, jie iš esmės siekia ekonominès naudos sau. Antra vertus, Kijevas vis dažniau ėmė pabrèžti, kad VEE jị labiausiai domina dvišalių santykių su Rusija vystymas. Šias tendencijas patvirtina rugpjūčio mèn. pabaigoje Rusijos Federacijoje Kazanëje vykęs VEE viršūnių susitikimas. Jo metu Ukraina situacijos neaštrino, parengé keliolika įvairių iniciatyvų, taip pat visaip stengėsi pabrèžti Rusijos ir Ukrainos dvišalių santykių svarbą 28 .

Pažymėtina, jog Kremliaus politikoje Ukrainos atžvilgiu reiškėsi ir dar viena politinè linija, kurią sąlygiškai pavadintume revanšine. Jos tikslas būtu politinès įtakos Ukrainoje atkūrimas ir apskritai Rusijos įtakos vakarinejje NVS dalyje stiprinimas. Šią politinę liniją bene aiškiausiai įvardijo Kremliaus „,politinis konsultantas“ Glebas Pavlovskis. Analitiko požiūriu, Rusijos valdžia Ukrainoje padariusi lemtingą klaidą, nes "dirbo" tik su politiniu elitu, ignoruodama ",socialinį veiksnį“, t. y. įvairias nevyriausybines organizacijas. Po V. Juščenkos pergalès Maskva privalanti aktyviau bendradarbiauti su opozicinèmis naujajam režimui struktūromis, jas panaudodama savo interesams igyvendinti. (Anot G. Pavlovskio: ....,ponas Juščenka negali būti laikomas asmeniu, turinčiu išimtines teises išreikšti Ukrainos visuomenès, politinių ir nevyriausybinių organizacijų interesus “29.) Taigi artimiausias Maskvos uždavinys būtų pasiekti, jog Rados rinkimus (2006 metų kovo mẻn.) laimètų opozicinès naujajam režimui prorusiškos jègos ${ }^{30}$.

Juščenkos ir Timošenkos konfliktas, vis labiau aštrëjantys santykiai tarp politiniu jẻgų formuoja prielaidas Maskvai dar labiau suaktyvinti politiką Ukrainoje. Antra vertus, atrodo, jog bent jau dalis Ukrainos politinio elito, siekdami stiprinti savo politines pozicijas, stengiasi kaip galima aktyviau išnaudoti ,"Maskvos veiksnį“ (tikètina, jog artëjant rinkimams tai bus daroma dar aktyviau). To-

27 Ten pat.

28 „Ющенко: Украина будет участвовать в ЕЭП“, www.Korrespondent.net, 20050822.

${ }^{29}$ Sokor V., "Kremlin redefining policy in „post-soviet“ space”, Eurasia daily Monitor, February 8, 2005.

${ }^{30}$ Dar aštriau Ukrainos atžvilgiu pasisakẻ žinomas rusiškosios euroazijinės geopolitinės minties atstovas Duginas. Jo teigimu, Kremlius turètų ne tik bandyti politiškai izoliuoti Juščenką, bet ir skatinti Ukrainos rytuose separatistines tendencijas. 
kią politinę logiką diktuoja įsitikinimas, kad, norint laimėti rinkimus (pirmiausia rusiškuose šalies regionuose), būtina užsitikrinti Kremliaus paramą. Matyt, tokie ar panašūs svarstymai paskatino ekspremjerę Timošenko beveik slapčia vykti į Maskvą, o Rusijos prokuratūrai panaikinti baudžiamąją bylą buvusiai premjerei.

Vis dèlto efektyviausias Rusijos įtakos Ukrainoje instrumentas išlieka energetika. Šią prielaidą patvirtina 2005 metų pabaigoje tarp šalių kilęs dujų konfliktas ir jo pasekmės. Konfliktas baigėsi ne tik neskaidriu Maskvos ir Kijevo susitari$\mathrm{mu}$, bet ir sukèlè dar vieną politinę krizę Ukrainoje. Oponuojančios Juščenkai politinès jëgos Radoje apkaltino Jechanurovo vyriausybę nemokejimu derètis su Rusija ir motyvuodamos įsigaliojusia politine reforma, ją atstatydino. Už vyriausybès atstatydinimą kartu balsavo Janukovičiaus ir Timošenkos politiniai blokai.

Taigi dujų konflikto „sureguliavimas“ nepakẻlè prezidento Juščenkos prestižo, prieštaravimai tarp Oranžinès revoliucijos bendražygių dar labiau paaštrejo, o Janukovičiaus ir Regionų partijos pozicijos sustiprèjo. Apskritai galima teigti, jog, artëjant rinkimams ị Aukščiausiają Radą, Maskva sustiprino savo pozicijas Ukrainoje. Antra vertus, nepriklausomai nuo to, kokia vyriausybė bus sudaryta po kovo mèn. įvyksiančių Rados rinkimu, ji pirmiausiai bus priversta su Rusija spręsti dujų kainos ir dujų tiekimo klausimus. (Pagal susitarimą, „kompromisinè" dujų kaina Ukrainai galioja tik iki 2006 metų liepos mèn.) Manytume, jog būtent energetika artimiausioje ateityje ir bus svarbiausias Rusijos politinès įtakos Ukrainoje išsaugojimo instrumentas.

\subsection{Ukraina ir Vakarai: gilesnès integracijos link?}

Paprastai teigiama, jog iki Oranžinės revoliucijos Vakarų struktūros, tai labiau būdinga ES, prioritetiniais NVS erdvèje laikè santykius su Rusija. Tuoj po Juščenkos pergalès imta svarstyti, ar neįvyks lūžis Vakarų ir Ukrainos santykiuose. Manytume, jog panašiai kaip Juščenka Vakarų atžvilgiu, taip ir Vakarai Ukrainos atžvilgiu susiduria su dilema: ES ir NATO, plèsdami bei stiprindami bendradarbiavimą su Ukraina, kartu stengiasi vystyti kooperacinius santykius su Rusija ir nenorėtu, kad bendradarbiavimas su Kijevu komplikuotu santykius su Maskva.

Manytume, jog tokiai politinei ir geopolitinei logikai labiau linkusi pasiduoti ES. Tiesa, reikia turèti galvoje, jog anaiptol ne visų ES svarbiausių institucijų bei šalių - nariu pozicijos bendradarbiavimo su Ukrainos ir jos narystés Sajungoje klausimu sutampa. Naujos ES narès (pirmiausia Lenkija) tuoj po revoliucijos pabandè kelti Ukrainos narystės ES idèją. (Už glaudesnių santykių su Ukrainą plètrą taip pat pasisakè ir Skandinavijos šalys.) Aktyviai bendradarbiavimo su Ukraina stiprinimą paremė Europos Parlamentas. 2005 metų sausio mèn. 13 d. Parlamentas priėmè specialią rezoliuciją, kurioje nurodytos konkrečios bendradarbiavimo tarp ES ir Ukrainos stiprinimo priemonès bei užsiminta apie narystės Europos Sajungoje galimybę ${ }^{31}$.

\footnotetext{
${ }^{31}$ Gromadzki G., Sushko O., Vahl M., Wolczuk K., Wolczuk R., Will the Orange revolution bear fruit? EU-Ukrainian relations in 2005 and the beginning of 2006. Stefan Batory Foundation, Warsaw, 2005, p. 17-18.
} 
Kartu reikètų pažymėti, jog Europos Taryba ir Komisija santykiuose su Ukraina laikėsi kur kas atsargesnès pozicijos. Nors Briuselis sveikino naują "strateginį Ukrainos pasirinkimą reformuotis ir demokratizuotis" ${ }^{\text {"32 }}$, tačiau jis ir toliau linkęs „pristabdyti“ Ukrainos eurointegracinį entuziazmą bei atsisakè traktuoti Kijevą kaip potencialią ES valstybę - narę. Pirmiausia Kijevui buvo aiškiai pasakyta, kad kelti narystès klausimą per anksti, kaip ir diskutuoti, , ar ES durys atviros, ar uždarytos". Anot Europos Komisijos išoriniu reikalų komisarės Benitos Ferrero-Waldner, ES gali derètis dèl privilegijuotos partnerystės statuso suteikimo Ukrainai, bet ne dèl narystės ES. Be abejonės, tokią ES poziciją lèmè ne tik ir galbūt ne tiek Kremliaus reakcija, bet svarbios vidinès priežastys institucinis Europos Sajungos neapibrezžtumas ir objektyvus Ukrainos nepasirengimas. Todèl visiškai suprantama, kad ES naujajai Ukrainos valdžiai pasiūlè sugrį̌ži prie Veiksmų plano idèjos. Briuselio manymu, taip bent jau per trejus metus būtų apibrèžta, kaip bus bendradarbiaujama su Ukraina, ir kartu atsiribota nuo ,ikyrių“ klausimų dèl Ukrainos narystės Europos Sajungoje.

Veiksmu planas buvo baigtas rengti dar 2004 metu gruodžio mèn. Jis numatè svarbiausias ES ir Ukrainos bendradarbiavimo kryptis, tačiau nieko nekalbëjo apie narystès perspektyvą. Tiesa, atsižvelgdama į demokratinius pokyčius Ukrainos politikoje ir reikšdama paramą jiems, ES Veiksmų planą (sausio mèn. 31 d.) papildè. Veiksmu planas buvo papildytas punktais - priemonèmis, kurios turètų dar labiau pagilinti Sajungos bendradarbiavimą su Ukraina. Šie papildymai numato rinkos ekonominės padėties Ukrainai suteikimą, paramą narystei PPO, prekybos režimo liberalizaciją. Taip pat žadama pradèti derybas dèl laisvos prekybos zonos sukūrimo 2006 metais bei supaprastinti vizu režimą. Nors veiksmų planas ir ne visiškai tenkino Kijevo lūkesčius, vis dẻlto 2005 metais vasario mèn. 21 d. ES ir Ukraina ji pasirašè.

Siekdama gilinti bendradarbiavimą su ES, Ukrainos vyriausybė įsteigė specialaus vicepremjero Europos integracijai postą bei parengè konkretu Veiksmų plano igyvendinimo tvarkarašti. Kartu naujosios valdžios pareigūnai pažymi, kad Kijevui dar toli iki praktinio tvarkaraščio igyvendinimo: nèra aiškumo tarp atskirų žinybų bei jų sprendimu priẻmimo tvarkos, žinybos tarpusavyje nesidalija informacija, trūksta kvalifikuotų kadrų ir pagaliau baiminamasi, ar praktinis kai kuriu „,namų darbų“ atlikimas euro-integracijos srityje neigiamai neatsilieps 2006 metų kovo mèn. rinkimų rezultatams ${ }^{33}$. Prezidentas V. Juščenka taip pat ne kartą kalbejjo apie būtinybę intensyviai vykdyti „namų darbus“. Anot prezidento, jo šalis, siekdama narystès, privalo priimti 350-400 nauju įstatymų arba ju pataisu, o derybas dẻl narystės pradèti tik po Veiksmų plano igyvendinimo ${ }^{34}$.

Mažai tikètina, jog ES ir Ukrainos santykiuose iki 2006 metų pavasario

\footnotetext{
${ }^{32}$ Gromadzki G., Lopata R., Raik K. Neighbours or Relatives? Finnish, Lithuanian and Polish perspectives on the EU's policy towards its new Eastern neighbourhood. Draft paper, p. 26. ${ }_{33}$ Rybachuk O., „Domestic Challenges to Ukraine's Europeanisation“, April 26, 2005, Kiev. Roundtable seminar „Neigbours or Relatives?" organized by the Finnish Institute of International Affairs in co-operation with the Embassy of Finland in Ukraine.

${ }^{34}$ „Ющенко уверен о вступлении в ЕC“, www.Korrespondent.net, 20050513.
} 
įvyktų kokių nors reikšmingesnių pokyčių. Tiesa, 2005 metų gruodžio 1 d. Kijeve Europos Sajungos ir Ukrainos viršūnių susitikime Ukraina buvo pripažinta rinkos ekonomikos šalimi. Buvo pasisakyta ir už kuo greitesnį Ukrainos įstojimą į PPO, o tai leistu igyvendinti svarbią Veiksmų plano nuostatą: pereiti prie derybų dèl laisvos prekybos zonos sukūrimo. Tačiau kada tokios derybos gali prasidèti-neaišku. Politinès krizès, įvairių verslo grupių nesutarimai sutrukdè reikalingų stojimui ị PPO dokumentu prièmimą. Tai reiškia, jog ne tik gali būti tikslinamas Ukrainos eurointegracinis tvarkaraštis, bet ir, kas dar svarbiau, prezidentas Juščenka rinkimų metu negalès pasigirti jokiais konkretesniais pasiekimais dèl santykių su ES.

Atrodo, jog apskritai ES bendraudama su Ukraina laikysis atsargios politikos. Tokią prielaidą patvirtina ES laikysena Rusijos ir Ukrainos dujų konflikto metu. Iš esmès Europos Sajunga užėmè neutralią, nesikišimo į konfliktą poziciją ir galiausiai pasveikino Maskvą bei Kijevą pasiekus „kompromisinį“" susitarimą. Kalbant apie artimiausią ES ir Ukrainos santykiu perspektyvą, reikètu pažymèti, jog įtakos dvišaliams santykiams ir "bendradarbiavimo gilinimui" turès rinkimų į Aukščiausiajją Radą rezultatai. Laimëjus prorusiškoms jẻgoms, Briuselio ir Kijevo dialogas gali apskritai prarasti dinamiką.

Analizuojant JAV ir NATO santykių su Ukraina po Oranžinės revoliucijos perspektyvas, būtina atsižvelgti į kelias aplinkybes. Pirma, Aljanse nėra bendros nuomonès dèl Ukrainos narystės perspektyvų. Tačiau būtina pastebèti, jog formaliai prisijungimas prie NATO nèra toks komplikuotas kaip stojimas i ES. Antra, Ukrainos narystės NATO klausimą komplikuoja ta aplinkybė, jog narystę NATO remia maždaug 15-20 proc. Ukrainos gyventoju, kai tuo tarpu už narystę ES 2005 metų pradžioje pasisakè 44 proc. gyventoju. Trečia, būtina pažymėtina, jog JAV remia Kijevo siekius prisijungti prie Aljanso.

Pastaroji tendencija išryškëjo prezidento Juščenkos vizito ị JAV 2005 metu balandžio mèn. metu ${ }^{35}$. George W. Bushas pažadejjo paramą Ukrainai ne tik stojant įPPO, bet ir į NATO. (Beje, V. Juščenkos vizito Vašingtone metu vyko intensyvios abiejų šaliu generalitetų derybos.) Tiesa, Busho administracija bendradarbiavimo su Ukraina perspektyvas sieja su demokratijos stiprinimu ir laisvos rinkos pletote.

JAV nuostata gilinti Aljanso ir Ukrainos bendradarbiavimą atsispindejjo ir 2005 metų balandžio 21 d. Vilniuje vykusio neformalaus NATO užsienio reikalų ministrų susitikime, kur dalyvavo ir Ukrainos atstovai. Jo metu įvyko Ukrainos - NATO komisijos poseddis, kur Kijevui buvo pasiūlytas intensyvus dialogas su Aljansu. Tų pačių metų spalio mèn. neformalių NATO ir Ukrainos konsultacijų metu, kurios vyko Vilniuje, JAV Gynybos ministras Donaldas Ramsfeldas vèl parėmė Ukrainos sieki prisijungti prie Aljanso ${ }^{36}$. Po šio susitikimo Ukrainos valdžios atstovai pareiškè, jog kitais metais gali būti parengtas ir priimtas Ukrainos prisijungimo prie NATO planas (MAP) ${ }^{37}$. Vis dažniau imta mi-

\footnotetext{
${ }^{35} \mathrm{~V}$. Juščenkos vizito JAV išvakarèse įtakingas Senato respublikonu politinis komitetas išplatino specialią analitinę pažymą, kurioje Busho administracija raginama aktyviai svarstyti Ukrainos narystės NATO klausimą, didinti šaliai ekonominę paramą ir t.t. Dokumente pažymima, jog Ukrainos ateitis svarbi Vakarams saugumo, politinių bei ekonominiu interesu požiūriais. Žr. Укринформ, Украинцы заслуживает немедленой поддержки Америки, 20050404.

36 Силина Т., „Поверь в мечту - и в путь“ http://www.zerkalo-nedeli.com/op/show/570/ $51670 /, 20051029-1104$

37 Ten pat.
} 
nèti ir konkreti stojimo data - 2008 metai. (Tiesa, Vilniuje abi pusės sutaré, jog prisijungimo tempui įtakos turès tiek vykdomų Ukrainoje reformų efektyvumas ir, žinoma, rinkimų į Radą rezultatai.)

Manytume, jog tokią JAV politiką Ukrainos atžvilgiu pirmiausia sąlygoja geopolitinė logika: stiprindamas Ukrainos bendradarbiavimą su NATO, Vašingtonas siekia apriboti Rusijos įtaką ne tik vakarinëje NVS dalyje, bet ir apskritai Vidurio ir Rytų Europoje. Dèl tų pačių geopolitinių priežasčių JAV suinteresuota regioniniu Ukrainos vaidmens stiprëjimu. Skirtingai nei ES, Vašingtonas aktyviai parėmė Ukrainos bandymus atgaivinti Gruzijos, Ukrainos, Uzbekijos, Azerbaidžano ir Moldovos organizaciją, vadinamaji GUUAM (Uzbekijai iš organizacijos pasitraukus, ji virto GUAM). Šią tendenciją patvirtino ir 2005 metais balandžio $22 \mathrm{~d}$. įvykęs vadinamasis Kišiniovo viršūnių susitikimas, kuriame, be GUAM nariu, dalyvavo Lietuvos ir Rumunijos prezidentai bei JAV valstybės departamento atstova. (Atrodo, jog EK nenoredama komplikuoti santykių su Rusija, kuri GUAM laiko JAV geopolitiniu projektu, nutare susitikime nedalyvauti.) Viršūnių susitikime buvo kalbama apie bendradarbiavimo (pirmiausia energetikos srityje) stiprinimą, taip pat priimta speciali deklaracija, kurioje teigiama, jog svarbiausias ją pasirašiusių šalių tikslas - demokratijos įtvirtinimas Baltijos - Juodosios jūros rajone. JAV aktyviai parėmè ir dar vieną bendrą Ukrainos ir Gruzijos regioninį projektą - Demokratinio pasirinkimo bendrijos (DPB) sukūrimą. Idèja apie tokio junginio sukūrimą pirmą kartą iškelta 2005 metų rugpjūčio mèn. Formaliai organizacija buvo įsteigtą tų pačių metų gruodžio mèn. 1-2 d., t. y. tuo pat metu, kai Kijeve vyko ES ir Ukrainos viršūniu susitikimas. (Vėlgi bendrijos steigime EK, ES senbuvès nedalyvavo.) DPB steigime be Ukrainos ir Gruzijos aktyviai dalyvavo Moldova, Lietuva, Latvija, Estija, Rumunija, Makedonija, Slovėnija (Dalyvauti organizacijos veikloje buvo pakviesta ir Rusija, tačiau tik stebètojos vaidmenyje). Visos tos šalys į susitikimą delegavo savo prezidentus. Bendrija deklaravo siekị plètoti demokratiją Baltijos - Juodosios - Kaspijos jūros regione. Iš esmès DPB jos steigèjų suvokiama kaip alternatyva Rusijos dominuojamam NVS.

Apibendrinant galima teigti, jog G. Busho administracija savo politiką Ukrainoje pirmiausia grindžia realistine perspektyva ir geopolitine logika. Pagal ją demokratinè ir provakarietiška Ukraina vertinama kaip geopolitinis veiksnys, galintis atsverti Rusijos dominavimą Vidurio ir Rytų Europoje. Ši aplinkybẻ leistų daryti prielaidą, jog Vašingtonas rodys daugiau politinio aktyvumo Ukrainoje, o ne ES.

\section{Kelios pastabos vietoje išvadụ}

Galima teigti, jog Oranžinę revoliuciją Ukrainoje veikè tiek vidinės (oligarchinio režimo krizė, opozicijos sugebëjimas mobilizuoti visuomenę ir pan.), tiek išorinės aplinkybės (Vakarų ir Rusijos varžymasis dẻl įtakos Ukrainoje „revoliucionizavo" visuomenę). Kad ir kaip vertintume Oranžinės revoliucijos priežastis, būtina pažymèti, jog pagrindinis Oranžinės revoliucijos siekis buvo po- 
litinės sistemos demokratizacija. Todèl ją paremė didelè Ukrainos visuomenės dalis, tikriausiai todèl Oranžinè revoliucija turëjo tiek daug rẻmèjų demokratiniuose Vakaruose. Oranžinė revoliucija kūrẻ prielaidas ne tik Ukrainos politinès sistemos demokratizacijai, bet ir formavo kokybiškai naują Ukrainos ir Vakarų santykiu perspektyvą. Ukrainos užsienio politikoje vis labiau ėmè dominuoti provakarietiška, Atlanto kryptis.

Tolesnej jau „porevoliucinès“ Ukrainos raida parodè, jog tokio vektoriaus užsienio politikoje įgyvendinimas susiduria su įvairiais sunkumais. Pirma, siekiant glaudesnio bendradarbiavimo su Vakarų struktūromis, buvo būtina vykdyti ekonominę bei politinę reformą šalies viduje. Antra, norint igyvendinti politines bei ekonomines reformas, būtina, kad sutartu politinis elitas ir bent jau pakankamai didelès visuomenės dalies parama tokioms reformoms. Atrodo, jog naujajam Ukrainos politiniam elitui šių keliu, mūsų nuomone, tikslų iš principo nepavyko pasiekti. Situaciją komplikavo V. Juščenkos ir J. Timošenkos aljanso skilimas, prezidento, aiškiai pasisakančio už provakarietišką liniją užsienio politikoje, ittakos politinëje sistemoje mažẻjimas ir galiausiai Rusijos ir Ukrainos duju konfliktas, pasibaigęs ne visai skaidriu susitarimu.

Vertindami situaciją, susidariusią Ukrainoje, politikai bei analitikai dažnai teigia, jog 2006 m. kovo mėn. Rados rinkimų rezultatai turès ypatingą reikšmę tolesnei Ukrainos raidai, jos užsienio politikos krypčiai. Jei rinkimus laimètu „vakarietiškos“ jëgos, tai įtvirtintų Oranžinès revoliucijos iškovojimą ir jos naują užsienio politikos krypti, jei vis dèlto laimètu „prorusiškos“ - pokyčiai užsienio politikoje taptų beveik neišvengiami. Apskritai su tokiais svarstymais galima sutikti. Tačiau manytume, jog juos būtina papildyti. Demokratiniai, skaidrūs, vakarietiškus standartus atitinkantis rinkimai Ukrainoje reikš, jog šalis vystosi pagal kitoki, skirtingą nuo Rusijos, politinès raidos modelį. 